\title{
A - C.A.N.V.A.S (CEREBELLAR ATAXIA, NEURONOPATHY AND VESTIBULAR AREFLEXIA WITH AUTONOMIC DYSFUNCTION): A FASCINATING CLINICAL PORTRAIT
}

\author{
Carlo Canepa-Raggio \\ Department of Neurology, James Paget University Hospital, \\ Great Yarmouth, Norfolk, UK
}

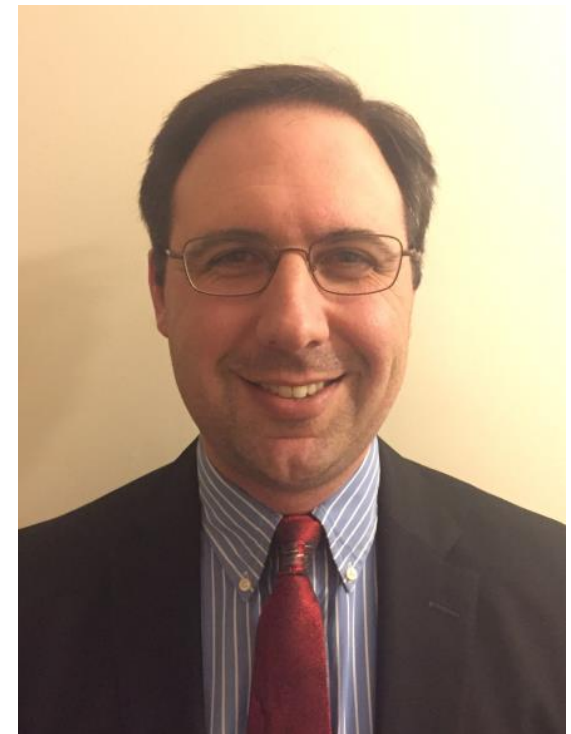

with autonomic dysfunction.

57-year-old male patient with a 30-year history chronic cough, balance difficulties (most noticeable in the dark), ataxia and sensory neuropathy. There was also evidence of orthostatic hypotension and hypohydrosis. Examination revealed downbeat nystagmus, an abnormal visually-enhanced vestibulo-ocular reflex, length-dependent sensory neuropathy, high-stepping tandem ataxia and bilateral dysmetria. MRI brain shows marked vermian cerebellar atrophy (more noticeable in lobes VI and VIIa/b) and nerve conduction studies reveal absent sensory conductions (ganglionopathy). Genetic testing for Friedrich's ataxia, spinocerebellar ataxia and hereditary motor sensory neuropathy (Charcot-Marie-Tooth disease) were all negative. Sural nerve biopsy showed pattern of severe loss of myelinated fibres. This patient was diagnosed with cerebellar ataxia, neuronopathy (ganglionopathy) and vestibular areflexia

Keywords: ataxia, neuronopathy, vestibular areflexia, autonomic dysfunction.

\section{Резюме \\ МОЗОЧКОВА АТАКСІЯ, НЕЙРОНОПАТІЯ ТА ВЕСТИБУЛЯРНА АРЕФЛЕКСІЯ З ВЕГЕТАТИВНОЮ ДИСФУНКЦІЄЮ (А-CANVAS СИНДРОМ): ЗАХОПЛЮЮЧИЙ КЛІНІЧНИЙ ПОРТРЕТ \\ Carlo Canepa-Raggio \\ Неврологічне відділення, університетська лікарня James Paget, \\ Грейт-Ярмут, Норфолк, Сполучене Королівство \\ У статті описується 57-річний пацієнт з 30-річним анамнезом хронічного каш- лю, порушенням рівноваги (більш вираженого в темряві), атаксією та сенсорною полі- нейропатією. Були також ознаки ортостатичної гіпотензії та гіпогідроза. Обстеження виявило ністагм з швидким компонентом вниз, патологічний візуально-посилений вес- тибуло-окулярний рефлекс, сенсорну полінейропатію, атаксію та двосторонню дисмет- рію. На МРТ головного мозку була виявлена значна атрофія черв'яка мозочка (більше помітна в зонах VI і VIIa/b), а електроміографія виявила відсутність сенсорної провід-}


ності (гангліонопатія). Генетичне тестування виключило атаксію Фридрейха, спіноцеребелярну атаксію та спадкову моторно-сенсорну нейропатію (хвороба Шарко-МаріТута). Біопсія литкового нерва показала виражене зменшення числа мієлінізованих волокон. У цього хворого була діагностована мозочкова атаксія, нейронопатія (гангліонопатія) і вестибулярна арефлексія з вегетативною дисфункцією (A-CANVAS синдром).

Ключові слова: атаксія, нейронопатія, вестибулярна арефлексія, вегетативна дисфункція.

\section{$\Rightarrow$ \\ РеЗюМЕ
МОЗЖЕЧКОВАЯ АТАКСИЯ, НЕЙРОНОПАТИЯ И ВЕСТИБУЛЯРНАЯ АРЕФЛЕКСИЯ С ВЕГЕТАТИВНОЙ ДИСФУНКЦИЕЙ (А-CANVAS СИНДРОМ): ЗАХВАТЫВАЮЩИЙ КЛИНИЧЕСКИЙ ПОРТРЕТ Carlo Canepa-Raggio \\ Неврологическое отделение, университетская больница James Paget, Грейт-Ярмут, Норфолк, Соединенное Королевство \\ В статье описывается 57-летний пациент с 30-летним анамнезом хронического} кашля, нарушением равновесия (более выраженного в темноте), атаксией и сенсорной полинейропатией. Имелись также признаки ортостатической гипотензии и гипогидроза. Обследование выявило нистагм с быстрым компонентом вниз, патологический визуально-усиленный вестибуло-окулярный рефлекс, сенсорную полинейропатию, атаксию и двустороннюю дисметрию. На МРТ головного мозга была обнаружена значительная атрофия червя мозжечка (более заметная в зонах VI и VIIa/b), а электромиография выявила отсутствие сенсорной проводимости (ганглионопатия). Генетическое тестирование исключило атаксию Фридрейха, спиноцеребеллярную атаксию и наследственную моторно-сенсорную нейропатию (болезнь Шарко-Мари-Тута). Биопсия икроножного нерва показала выраженное уменьшение числа миелинизированных волокон. У этого больного была диагностирована мозжечковая атаксия, нейронопатия (ганглионопатия) и вестибулярная арефлексия с вегетативной дисфункцией (A-CANVAS синдром).

Ключевые слова: атаксия, нейронопатия, вестибулярная арефлексия, вегетативная дисфункция.

\section{Case Presentation}

57-year-old male patient with a 30-year history of chronic cough, allergy to erythromycin and seasonal asthma is seen in the neurology clinic for a 20-year history of balance difficulties, which were first noticed whilst walking his dog a night and when walking though dark environments. Sudden head movements and a change in direction whilst walking would also elicit imbalance. There was no double vision, nausea or vomiting. No family history of balance difficulties was noted either. Mild tinnitus in right ear but no hearing loss had been present since the onset. Three years ago, he started presenting bilateral, sharp-like shooting pain in both feet and ankles. No sphincter dysfunction was no- ticed. He also had a long-standing history of reduced sweating in feet and mild orthostatic hypotension, first noticed approximately 10 years ago.

On examination there was high-stepping tandem ataxia, bilateral dysmetria, preserved strength in all four limbs, absent reflexes in both lower limbs and reduced pinprick sensation in upper left limb and reduced vibrational and pinprick perception in both lower limbs in the stocking distribution. Visual examination showed an abnormal visually enhanced vestibular ocular reflex, determined by saccadic movements upon inducing oculocephalic manoeuvre, very slight jerky smooth pursuit, downbeat nystagmus (in particular on left gaze), misdirected directed vertical sac- 
cades in the horizontal direction and normal optic nerves and macula.

Nerve conduction study showed normal motor function but completely absent sensory action potentials in all four limbs. MRI head (in 2016) demonstrated vermian cerebellar atrophy, more noticeable in the primary fissure, lobes VI and VIIa/VIIb and pre-Pyramidal fissure (figure 1). Repeat MRI (in 2018) showed similar findings, with a subtle worsening of lobe VI and VII atrophy along with a widening of the pre-Pyramidal fissure (figure 2). Spinal MRI showed mild spondylitic changes at $\mathrm{C} 4 / \mathrm{C} 5$ and at L3/L4 without ste- nosis. Testing for spinocerebellar ataxia, hereditary sensorimotor neuropathy (CharcotMarie-Tooth disease) and Friedrich's ataxia were negative. A (right) sural nerve biopsy showed a severe loss of myelinated fibres, marked hydropic change in the Schwann cells, no amyloid filaments and scanty lymphocytes and macrophages cuff epineural arterioles. A video-fluoroscopy was done as well, demonstrating a delayed swallowing time but no choking episodes. Based on these findings, the patient was diagnosed with cerebellar ataxia, ganglionopathy and vestibular areflexia with autonomic dysfunction.

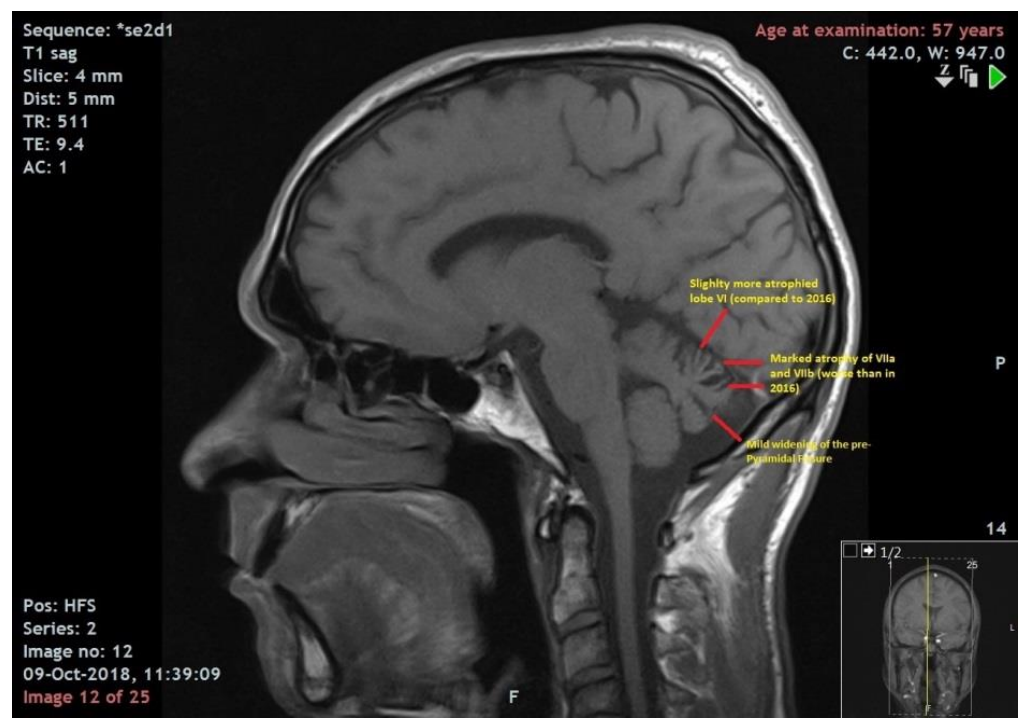

Figure 1. MRI Head (2016): cerebellar atrophy more manifest in the vermix, with focus on primary fissure, lobes VI and VIIa/b and pre-Pyramidal fissure

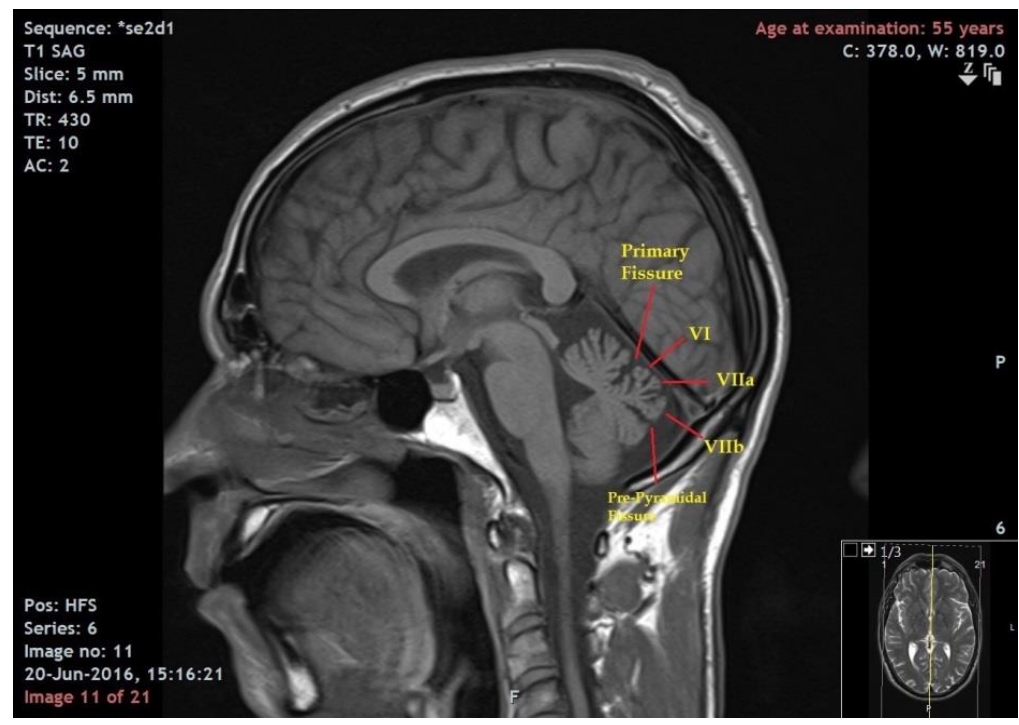

Figure 2. MRI Head (2018): mild worsening of the cerebellar atrophy, particularly in the lobes VI and VIIa/b 


\section{Differential Diagnosis}

There is a very short list of conditions that can cause simultaneous vestibular and cerebellar dysfunction: SCA3, Friedriech's ataxia, MSA-C, idiopathic cerebellar ataxia with bilateral vestibulopathy (iCABV) and Wernicke's encephalopathy (CJD and Cogan disease are also in the list, but these are much less common). Before reaching the diagnosis of CANVAS, these conditions have to be excluded. We must search for the triad of: cerebellar impairment, bilateral vestibulopathy and non-length dependent sensory deficit. SCA3 (Machado Joseph disease) can present with abnormal VVOR, sensory neuropathy and cerebellar ataxia; however, in this case, there was no pedigree consistent of dominant inheritance and the nerve conduction demonstrated purely sensory loss without motor involvement, which goes against the classical mixed motor-and-sensory loss seen in SCA. The MRI findings in SCA is also different than in CANVAS: normal cerebellar hemispheres with enlargement of IV ventricle with atrophy of lobules I, II, IV, VIII and IX. Genetic testing for multiple SCA subtypes was negative. Friedrich's ataxia can also cause severe vestibulopathy with absence SNAPs (and normal motor conduction), but it was ruled out mainly due to the patient's age and negative genetic investigations. The MRI brain did not show either the classical hotcross-bun sign or pontine atrophy seen in multisystem atrophy type; furthermore, there is no vestibulopathy nor non-length dependent sensory deficit in multisystem atrophy type C. Downbeat nystagmus is typical in patients with CANVAS (as this patient presented), however, it can also be present in MSAC. On the other hand, features of MSA-C that are not present in CANVAS are: rapid-eyemovement sleep disorder, parkinsonism, and brainstem atrophy (none of which this patient presented). No features were noticed for Wernicke's encephalopathy. Therefore, the only condition compatible with the patient's constellation of symptoms was CANVAS with autonomic features

\section{Discussion}

There are three clinical abnormalities in CANVAS: (1) cerebellar ataxia, (2) neu- ronopathy (ganglionopathy) and (3) bilateral vestibular areflexia. The sum effect of these three abnormalities causes ataxia and abnormal compensatory eye movements. There can also be autonomic dysfunction (A-CANVAS or CANVAS plus), such as in this case who presents orthostatic hypotension and hypohydrosis.

While smooth pursuit (SP) and saccades are voluntary eye movements, the vestibularocular reflex (VOR) - which is elicited by the oculo-cephalic maneuver (or "doll's eye" maneuver) - is involuntary. It can, however, be voluntarily suppressed (a cerebellar dysfunction such as that seen in Joubert Syndrome (see Canepa et al [1]), can block the voluntary suppression of the VOR). The optokinetic reflex (OKR) is another compensatory eye movement, which can be elicited looking at the oscillation of black and white strips, for example; the normal reflex is manifested by symmetrical nystagmus, in which the rapid phase (saccades) moves in the opposite direction to that of the moving object; any asymmetry in the reflex nystagmus reflects a cerebellar or brainstem dysfunction. In summary, then, there are two centrallydependent (cerebellar) eye movements (SP and OKR) and only one peripherallydependent (vestibular) movement (VOR). The synchronic use of these three compensatory eye movements is called the visuallyenhanced vestibular ocular reflex or VVOR. This patient had downbeat nystagmus and abnormal visually-enhanced vestibular ocular reflex.

In 2004, Migliaccio et al [2] (following Bronstein et al [3] 1991), proposed that in patients who present selective bilateral vestibulopathy associated with cerebellar ataxia (CABV), the characteristic clinical sign is an abnormal VVOR [4], which suggests a combined lesion of the cerebellum and of the vestibular nuclei (pons). In such cases, as a result of a loss of VOR + SP + OKR, patients are unable to make full compensatory smooth eye movements, resulting in jerky saccadic movements [5] as seen in our patient (see video). On the other hand, patients with loss of only the VOR or only SP + OKR, can still make smooth compensatory eye movements and maintain gaze. An abnormal VVOR is 
found only in a handful of conditions: multisystem atrophy type C (MSA-C), spinocerebellar ataxia type 3 (Machado Joseph [6, 7]) 6 and 7, Friedrich's ataxia, Cogan syndrome and of course, CANVAS. Therefore, before reaching a diagnosis of CANVAS, these other conditions must be excluded. Spinocerebellar ataxia and Friedrich's ataxia were excluded in this patient through genetic testing; there was no hot-cross-bun sign on MRI for MSA-C nor was there systemic symptoms, photophobia, keratitis, tinnitus or hearing loss to suggest Cogan's syndrome. Very importantly, in CANVAS patients, there is no cochlear involvement, therefore no hearing loss.

It has been proven that patients with CANVAS have multiple ganglionopathies [8, 9] (instead of neuropathy, as previously assumed), clinically manifested as a non-length dependent multimodality sensory deficit (mainly for pinprick and vibration) and absent reflexes. Generalized absence of sensory nerve action potentials (SNAPs) is the neurophysiological hallmark; this patient presented complete absence of SNAP in sural, ulnar and median nerves.

In 2011, Szmulewicz et al [10] reported the first biopsy results of a patient with CANVAS: diminution of vestibular (Scarpa's) ganglion cells bilaterally, atrophy of the facial nerves particularly affecting the geniculate ganglion and severe trigeminal ganglion atrophy. Hence, they concluded that the vestibular areflexia in CANVAS is not due to end-organ (labyrinthine) or central vestibular impairment but is due to a ganglionopathy.

The cerebellar involvement consists of anterior and dorsal vermis atrophy (vermal lobules VI, VIIa and VIIb), and laterally, atrophy of crus 1 (which corresponds to lobule VII [11]. This patient had a marked vermian cerebellar atrophy.

$\mathrm{Wu}$ et al (2014) [12] published the first scientific data regarding autonomic dysfunction in CANVAS. They reported an overall high incidence. Common autonomic symptoms include: light-headedness, postural hypotension, dry mouth/eyes, pale/blue feet, reduced feet sweating, general hypohydrosis, increased hand sweating, nauseas or vomiting after a small meal, persistent diarrhoea, con- stipation, urinary incontinence and erectile dysfunction. They proposed that autonomic dysfunction in CANVAS is the consequence of a primary ganglionopathy involving the autonomic, vestibular, facial, trigeminal and sensory ganglia.

Interestingly, $\mathrm{Wu}$ et al (2014) and Szmulewicz et al (2014) [13] report chronic cough as a relatively common symptoms, usually preceding the onset of somatosensory impairment and ataxia by many years. The cause is unknown, however, a vagal ganglionopathy and denervation hypersensitivity of the upper airways and oesophagus has been proposed. This patient presented a longstanding history of chronic, dry cough, preceding the onset of ataxia, visual problems and neuropathy. Interestingly, his 32-year-old son has also presented a chronic cough for about 5 years.

Szmulewicz et al (2016) [14] proposed diagnostic criteria for CANVAS and put forth a classification of possible, probable, definitive and pathologically definitive CANVAS. Possible CANVAS combines bilateral vestibular hypofunction, clinical evidence of cerebellar impairment, abnormal sensory conduction and exclusion of SCA3 and Friedreich's ataxia. Probably CANVAS requires evidence of an abnormal VVOR, cerebellar atrophy seen on MRI, sensory conduction abnormality and exclusion of SCA3 and Friedreich's ataxia. Clinically definitive CANVAS is diagnosed by the combination of abnormal VVOR (on video-oculography, video-nystagmography or rotational chair testing), characteristic cerebellar atrophy on MRI (anterior and vermis atrophy - lobules VI, VIIa and VIII - and lateral hemispheric atrophy affecting crus 1, corresponding to vermal lobule VII). Finally, pathologically definitive CANVAS requires positive biopsy findings (temporal bone pathology of a vestibular ganglionopathy). This patient has a clinically diagnosed CANVAS; no biopsy has been done.

\section{References}

1. Canepa C., Burton B., Muhith A., et al. An elusive ciliopathy: Joubert Syndrome. BMJ Case Report. 2017. doi:10.1136/bcr2017. 
2. Migliaccio A.A., Halmagyi G.M., McGarvie L.A., et al. Cerebellar ataxia with bilateral vestibulopathy: description of a syndrome and its characteristic clinical sign. Brain. 2004;127:280-293.

3. Bronstein A.M., Mossman S. and Luxon L.M. The neck-eye reflex in patients with reduced vestibular and optokinetic function. Brain. 1991;114:1-11.

4. Petersen J.A., Wichmann W.W., Weber K.P. The pivotal sign of CANVAS. Neurology. 2013;81:1642-1643.

5. Migliaccio A.A., Halmagyi GM, McGarvie LA, et al. Cerebellar ataxia with bilateral vestibulopathy: description of a syndrome and its characteristic clinical sign. Brain. 2004;127:280-293.

6. Burk K., Fetter M., Abele M., et al. Autosomal dominant cerebellar ataxia type I: oculomotor abnormalities in families with SCA1, SCA2 and SCA3. J Neurol. 1999;246(9):789-797.

7. Gordon C.R., Joffe V., Vainstein G. et al. Vestibulo-ocular areflexia in families with spinocerebellar ataxia type 3 (Machado-Joseph disease). J Neurol Neurosurg Psychiatr. 2003;74(1):1403-1406.

8. Szmulewicz D.J., Merchant S.N. and Halmagyi G.M. Cerebellar ataxia with neuropathy and bilateral vestibular areflexia syndrome (CANVAS): a histopath- ologic case report. Otol Neurotol. 2011;32(8):e63-5

9. Kuntzer, et al. Clinical features and pathophysiological basis of sensory neuronopathies (ganglionopathies). Muscle Nerve. 2004;30:255-268.

10. Szmulewicz D.J., Merchant S.N. and Halmagyi G.M. Cerebellar ataxia with neuropathy and bilateral vestibular areflexia syndrome (CANVAS): a histopathologic case report. Otol Neurotol. 2011;32(8): e63-5

11. Schmahmann, J.D., Doyon J. \& Petrides M. et al. MRI Atlas of the Human Cerebellum. Academic Press. San Diego, 2000.

12. Wu T.Y., Taylor J.M., Kilfoyle D.H., et al. Autonomic dysfunction is a major feature of cerebellar ataxia, neuropathy, vestibular areflexia "CANVAS" syndrome. Brain, 2014, Oct;137 (Pt 10):2649-56.

13. Szmulewicz D.J., McLean C., MacDougall H., et al. CANVAS an update: clinical presentation, investigation and management. Journal of Vestibular Research. 2014;24:465-474

14. Szmulewicz D.J., et al. "Proposed diagnostic criteria for cerebellar ataxia with neuropathy and vestibular areflexia syndrome (CANVAS)" Neurol Clin Pract. 2016;6(1):61-68. 